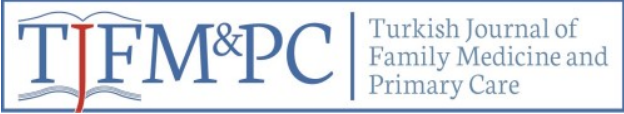

Original Research / Özgün Araştırma

\title{
Community-Based Cancer Screening: Reaching The Target Population
}

\author{
Toplum Tabanlı Kanser Taraması: Hedef Topluma Ulaşmak
}

\author{
Özden Gökdemir ${ }^{* 1}$, Mehtap Kartal ${ }^{2}$
}

\begin{abstract}
Objective: The aim of this study is to determine the risk factors and the results of the community-based screening program of the women who attended the Cancer Early Diagnosis, Screening, and Education Center between 2005-2011. Methods: This study was planned on a descriptive design. Data of the women who attend to cancer screening center between 2005-2011 years for breast cancer and cervical cancer screening program were collected retrospectively and evaluated. Incomplete forms were excluded. Results: Research has been completed by the records of 3162 women. The age of the study group was between 25-69 years old. The majority of them has been educated for 5 years and/or less, or not educated $(89 \%)$, more than one-third of patients had more than four birth $(38 \%)$, the breastfeeding rate was high $(93.6 \%)$, the oral contraceptive drugs and HRT medication usage ratios were low $(7.2 \%, 7.2 \%)$, respectively), the smoking rate was low $(14.9 \%)$. The number of women who consulted for cervix cancer screening was 215 in 2008 and 142 for breast cancer screening; by the end of June 2011. Those numbers increased to 1271 and 1012 , respectively. Conclusion: Community-based cancer screening programs are much more successful to reach the target population although single women, LGBT individuals, "working class" are still the missing parts of the puzzle.
\end{abstract}

Key Words: Community-based screening, opportunistic screening, breast cancer, cervix cancer, risk factors

\section{ÖZET}

Amaç: Bu çalışmanın amacı, 2005-2011 yılları arasında Kanser Erken Teşhis, Tarama ve Eğitim Merkezine toplum tabanlı tarama programı kapsamında başvuran kadınların risk etmenlerii ve sonuçlarını incelemektir. Yöntem: Bu çalışma tanımlayıcı desende planlanmıştır. Kanser tarama merkezine 2005-2011 yılları arasında başvuran kadınların meme kanseri ve serviks kanseri tarama programı verileri geriye dönük olarak toplanıp incelendi. Eksik formlar çalışma dışı bırakıldı. Bulgular: Araştırma 3162 kadının kayıtlarıyla tamamlanmıştır. Çalışma grubunun yaşı, 25-69 yaş arasındaydı. Büyük çoğunluğu 5 yıl ve/ya altında eğitim görmüşler ya da eğitim görmemişlerdi (\%89), üçte birinden fazlası dörtten fazla doğum yapmıştı $(\% 38)$ ve hormon replasman tedavisi $(\% 7,2)$ ile sigara kullanım oranları $(\% 14,9)$ düşük bulundu. Serviks kanseri taraması için konsulte edilen kadın sayısı 2008'de 215, meme kanseri taraması için 142 iken; 2011 Haziran sonunda, bu sayılar sırasıyla 1271 ve 1012 'ye yükseldi. Sonuç: Toplum tabanlı kanser tarama programları, hedef topluma ulaşabilmek için çok daha başarılı olmasına karşın; bekar kadınlar, LGBT bireyler ve çalışan kadınlar hala bu bulmacanın eksik parçalarıdır.

Anahtar Sözcükler: Toplum Tabanlı Tarama, Fırsatçı Tarama, Meme kanseri, Serviks kanseri, Risk Etmenleri

Received date/ Geliş tarihi: 11.03.2020, Accepted date/ Kabul tarihi: 28.04.2020

${ }^{1}$ Izmir University of Economics, Faculty of Medicine, Izmir-TURKEY.

${ }^{2}$ Department of Family Medicine, Faculty of Medicine, Dokuz Eylul University,Izmir-TURKEY.

*Address for Correspondence / Yazışma Adresi: Özden Gökdemir, Izmir University of Economics, Faculty of Medicine, Izmir-TURKEY.

E-mail: gokdemirozden@gmail.com ozden.gokdemir@ieu.edu.tr

Gokdemir O, Kartal M. Community-Based Cancer Screening: Reaching The Target Population. TJFMPC, 2020;14(3):368-376.

DoI: $10.21763 /$ tjfmpc. 696263 


\section{INTRODUCTION}

On a global scale, breast cancer is the most common cancer among women $(23 \%$ of the total cancer cases) and the most common cause of cancer death (14\% of the cancer deaths). The incidence of breast cancer in women has been reported that cases increased by $20 \%$ according to the latest IARCS report. ${ }^{1}$ The Cancer Statistics have still reported breast cancer as the first of all the cancers for the females as a new case while the second reason of death. ${ }^{2,3}$ In Turkey, one of the four women have breast cancer. ${ }^{4}$ In women receiving a breast cancer diagnosis, 5-year survival rates, according to all the stages, were reported as $83 \%$ in developed countries and $53 \%$ in developing countries. This difference is explained by the fact that screening by mammography provides early diagnosis and better treatment possibilities in developed countries. ${ }^{4-6}$

Worldwide, cervical cancer is the third most common cancer ${ }^{7,8}$ affects women, and its mortality rate can be reduced by early diagnosis, as in the breast cancer screening program. ${ }^{7}$ Due to the successful implementation of screening programs in developed countries, cervical cancer is listed as 6th$10^{\text {th }}$ most common, while the second place in the developing countries. Effective implementation of cervical cancer screening programs reduces both the incidence and mortality rates in developed countries. 9

Cancer screening is a recommended and broadly available preventive service. ${ }^{10}$ In preventive health care, the goal is to reach as many individuals as possible and to reduce deaths and disability due to illness. ${ }^{11}$

In this study, it was aimed to determine the risk factors and the results of the community-based cancer screening program of the women for breast and cervical cancer at Cancer Early Diagnosis, Screening and Training Center between 2005-2011, which shows the transition from opportunistic screening program to the community-based one.

\section{MATERIALS and METHODS}

This research is a retrospective descriptive study based on patient registration forms of women participating in the breast cancer and cervical cancer screening program between 2005 and 2011 at Cancer Early Diagnosis, Screening and Training Center (CEDSTC) in rural. For the implementation of the survey, the issue of T.C. The Public Health Directorate has obtained the necessary permits from the $\mathrm{xxx}$ Non-Interventional Clinical Investigations Ethics Committee, number 50022329/299-2811, and the xxx Public Health Directorate on 31.01.2014 and with the protocol No. 1330-GOA dossier and $2014 / 29-33$ on 25.09 .2014 .

\section{Patient Information Form}

This form includes the information about the use of oral contraceptives, menopausal status, breastfeeding status, total breastfeeding duration, smoking status, smoking habits, height, weight, BMI, the age of menarche, the age of first marriage, menopausal shape, menopausal age, HRT use, detailed medical history of chronic diseases, use of medication history of previous breast disease, biopsy status-outcome report, chronic diseases, drugs used regularly, family history of breast cancer, family history of cancer, age and onset date of a complaint related to the application of breast cancer screening, mammography-breast ultrasonography (USG) application, radiology and pathology reports.

\section{Statistical Analysis}

Information obtained from the CEDSTC registration form and patient information form. The data were entered into the SPSS 15.0 package program for statistical analysis. Mean, the standard deviation for descriptive continuous variables, the frequency and percentage distributions for categorical variables were calculated.

\section{RESULTS}

\section{Descriptive Characteristics of Women}

The study was completed with file records of 3162 women aged 25-69 years. More than half of them were educated $(61 \%)$ to the primary education level (Table1). 


\begin{tabular}{|c|c|c|c|c|c|c|c|}
\hline & & \multicolumn{2}{|c|}{ Breast USG $(n=2063)$} & \multicolumn{2}{|c|}{$\begin{array}{c}\text { Mammography } \\
(n=2147)\end{array}$} & \multicolumn{2}{|c|}{$\begin{array}{c}\text { Cervical Smear } \\
(\mathrm{n}=2833)\end{array}$} \\
\hline & & $\mathrm{n}$ & $\%$ & $\mathrm{n}$ & $\%$ & $\mathrm{n}$ & $\%$ \\
\hline \multirow{3}{*}{ Age Groups (year) } & $<35$ & 256 & 12.4 & 8 & 0.4 & 276 & 9.7 \\
\hline & $35-44$ & 745 & 36.1 & 599 & 27.8 & 952 & 33.6 \\
\hline & $>44$ & 1062 & 51.5 & 1540 & 71.8 & 1605 & 56.7 \\
\hline \multirow{2}{*}{ Marital Status } & Single & 39 & 1.8 & 28 & 1.3 & 4 & 0.1 \\
\hline & Married & 2024 & 98.2 & 2119 & 98.7 & 2829 & 99.9 \\
\hline \multirow{5}{*}{ Education Level } & Illiterate & 387 & 18.8 & 540 & 25.2 & 592 & 20.9 \\
\hline & Literate & 157 & 7.6 & 203 & 9.5 & 216 & 7.6 \\
\hline & Primary School & 1298 & 62.9 & 1244 & 57.9 & 1746 & 61.6 \\
\hline & Secondary School & 159 & 7.7 & 112 & 5.2 & 199 & 7.1 \\
\hline & High School & 62 & 3.0 & 48 & 2.2 & 80 & 2.8 \\
\hline \multirow{2}{*}{ Occupation } & *Not Occupied & 2001 & 96.6 & 2090 & 97.3 & 2750 & 97.1 \\
\hline & Have a job & 62 & 3.4 & 57 & 2.7 & 83 & 2.9 \\
\hline
\end{tabular}

${ }^{*}$ Not Occupied $=$ Housewife + Retired + Student

Of the women participating in the screening program, $75.20 \%$ stated that their menarche age is 14 years or less, and $25.85 \%$ of the women married between the ages of 14-17. More than one-third of the women had more than four pregnancies
(38.60\%). Breast-feeding was reported by $93.60 \%$. Contraceptive pills were used by $20.80 \%$, and $56 \%$ were not menopausal. The median age for menopause was $46.53 \pm 5.76$ (Table2).

\begin{tabular}{|c|c|c|c|c|c|c|c|}
\hline & & \multicolumn{2}{|c|}{ Breast USG $(n=2063)$} & \multicolumn{2}{|c|}{$\begin{array}{c}\text { Mammography } \\
(\mathrm{n}=2147)\end{array}$} & \multicolumn{2}{|c|}{$\begin{array}{c}\text { Cervical Smear } \\
(\mathrm{n}=2833)\end{array}$} \\
\hline & & $\mathrm{n}$ & $\%$ & $\mathrm{n}$ & $\%$ & $\mathrm{n}$ & $\%$ \\
\hline \multirow{3}{*}{ Age of menarche (year) } & $<14$ & 1591 & 77.1 & 1566 & 72.9 & 2142 & 75.6 \\
\hline & $14-17$ & 456 & 22.1 & 556 & 25.9 & 666 & 23.5 \\
\hline & $>17$ & 16 & 0.8 & 25 & 1.2 & 25 & 0.9 \\
\hline \multirow{3}{*}{ Age at first labor (year) } & $<14$ & 58 & 2.8 & 60 & 2.8 & 53 & 1.9 \\
\hline & $14-17$ & 272 & 13.2 & 339 & 15.8 & 411 & 14.5 \\
\hline & $>17$ & 1733 & 84.0 & 1748 & 81.4 & 2369 & 83.6 \\
\hline \multirow{4}{*}{ Parity } & none & 121 & 2.5 & 110 & 5.1 & 102 & 3.5 \\
\hline & 1 & 177 & 8.6 & 80 & 3.7 & 146 & 5.2 \\
\hline & $1-4$ & 1203 & 58.3 & 1103 & 51.4 & 1623 & 57.3 \\
\hline & $>4$ & 622 & 30.6 & 854 & 39.8 & 962 & 34.0 \\
\hline \multirow{3}{*}{ Breast-feeding } & yes & 1925 & 93.3 & 2016 & 93.9 & 2709 & 95.6 \\
\hline & no & 135 & 6.55 & 126 & 5.9 & 119 & 4.2 \\
\hline & unknown & 3 & 0.15 & 5 & 0.2 & 5 & 0.2 \\
\hline \multirow{3}{*}{ Oral contraceptive } & yes & 153 & 7.4 & 168 & 7.8 & 198 & 7.0 \\
\hline & no & 1906 & 92.5 & 1975 & 92.0 & 2632 & 92.9 \\
\hline & unknown & 2 & 0.1 & 4 & 0.2 & 3 & 0.1 \\
\hline \multirow{5}{*}{$\underline{\text { Menopause }}$} & yes & 1235 & 59.9 & 930 & 43.3 & 1559 & 55.0 \\
\hline & no & 549 & 26.6 & 820 & 38.2 & 856 & 30.2 \\
\hline & premenopausal & 105 & 5.1 & 147 & 6.8 & 167 & 5.9 \\
\hline & unknown & 29 & 1.5 & 34 & 1.6 & 35 & 1.3 \\
\hline & surgical menopause & 145 & 6.9 & 216 & 10.1 & 216 & 7.6 \\
\hline \multirow{3}{*}{$\begin{array}{l}\text { Hormone replacement } \\
\text { therapy }\end{array}$} & Yes & 153 & 7.4 & 168 & 7.8 & 198 & 7.0 \\
\hline & No & 1906 & 92.5 & 1975 & 92.0 & 2632 & 92.9 \\
\hline & Unknown & 2 & 0.1 & 4 & 0.2 & 3 & 0.1 \\
\hline
\end{tabular}


The most commonly used drugs are those used for cardiovascular system diseases $(17.80 \%)$. Almost two-thirds of patients $(64.90 \%)$ stated that they did not use medication and, $58.30 \%$ were a non-smoker. Of patients, $48.50 \%$ were found to be below the BMI value of 24.90 .

Family history for breast cancer was found in $14.20 \%$ of the women, and the ratio of first-degree relatives was $4.70 \%$. When the family history of cancer was examined from the aspect of the degree in a relationship, $25.50 \%$ had first-degree relativity, and $18.20 \%$ had a second-degree relational cancer history. They said that $14.60 \%$ had lung cancer in the family, and $8.10 \%$ in first-degree relatives (Table 3).

It was determined that $67.90 \%$ had had mammograms, $65.20 \%$ breast USG, $89.60 \%$ cervical smear, and $2.80 \%$, biopsy.

\begin{tabular}{|c|c|c|c|c|c|c|c|}
\hline \multicolumn{8}{|c|}{ Table 3. Distribution of Women by Their Cancer Stories in Their Browsing Status } \\
\hline & & \multicolumn{2}{|c|}{ Breast USG $(\mathrm{n}=2063)$} & \multicolumn{2}{|c|}{$\begin{array}{l}\text { Mammography } \\
(n=2147)\end{array}$} & \multicolumn{2}{|c|}{ Cervical Smear $(\mathrm{n}=2833)$} \\
\hline & & $\mathrm{n}$ & $\%$ & $\mathrm{n}$ & $\%$ & $\mathrm{n}$ & $\%$ \\
\hline \multirow{2}{*}{$\begin{array}{l}\text { Familial history of } \\
\text { breast cancer }\end{array}$} & Yes & 318 & 15.4 & 316 & 14.7 & 404 & 14.3 \\
\hline & $\mathrm{No}$ & 1745 & 84.6 & 1831 & 85.3 & 2429 & 85.7 \\
\hline \multirow{2}{*}{$\begin{array}{l}\text { Familial history of breast } \\
\text { cancer (first-degree relative) }\end{array}$} & Yes & 104 & 5.1 & 110 & 5.1 & 134 & 4.7 \\
\hline & No & 1959 & 94.9 & 2037 & 94.9 & 2699 & 95.3 \\
\hline \multirow{2}{*}{$\begin{array}{l}\text { Familial history of } \\
\text { cancer }\end{array}$} & Yes & 1003 & 48.6 & 1079 & 50.3 & 1393 & 49.2 \\
\hline & No & 1061 & 51.4 & 1068 & 49.7 & 1440 & 50.8 \\
\hline \multirow{2}{*}{$\begin{array}{l}\text { Familial history of } \\
\text { lung cancer }\end{array}$} & Yes & 287 & 13.9 & 336 & 15.6 & 422 & 14.9 \\
\hline & $\mathrm{No}$ & 1776 & 86.1 & 1811 & 84.4 & 2411 & 85.1 \\
\hline
\end{tabular}

\section{Screening Program Results}

The sociodemographic characteristics of the women participating in the screening program are summarized in Table $2.71 .90 \%$ of the women with mammograms were older than 44 years old. This result was compatible with the guidelines. $56.70 \%$ of the women screened by the cervical smear method were older than 44 years old. More than $98 \%$ were married; the percent of women whom had had breastultrasonography was $98.20 \%$ while this percent was $98.70 \%$ for mammograms, and the percent of married women whom were screened by cervical smear was $99.90 \%$. The group screened by cervical smear had primary education, while only $2.80 \%$ of them had higher education. Women who participated in the survey had an employment rate of less than $24 \%$ $(23.20 \%$ of breast USG, $2.70 \%$ of mammograms, and $2.90 \%$ screened by cervical smear).

The distribution of the screening status of women by their obstetric characteristics is summarized in Table 3. Distribution of screening status of women according to their menopausal characteristics is summarized in Table 3. 59.90\% of the women with breast USG reports were not menopausal. 48.30\% of the mammography patients were menopausal (menopause with or without surgery). All screening was performed according to the national program.

Mammography was performed in $14.70 \%$ of those with a family breast cancer history. $5.10 \%$ of the women whom undergone mammograms had a history of breast cancer in first-degree relatives.

Most women reported as "never smoking" $(61.40 \%$ of breast USG patients, $60.60 \%$ of mammography patients, and $58.20 \%$ of cervical smear). Of the women who had breast USG, $24.30 \%$ had a BMI of over, $30.22 .2 \%$ of the mammograms were over $30 \mathrm{BMI}$. In the USG group, most used neither the contraceptive pills (79.5\%) nor hormone replacement therapy $(92.5 \%)$.

The number of women in the appropriate age range participating in the breast cancer screening program increased from 142 in 2008, to 712 in 2010 and 1012 in July 2011 (Figure 1). 


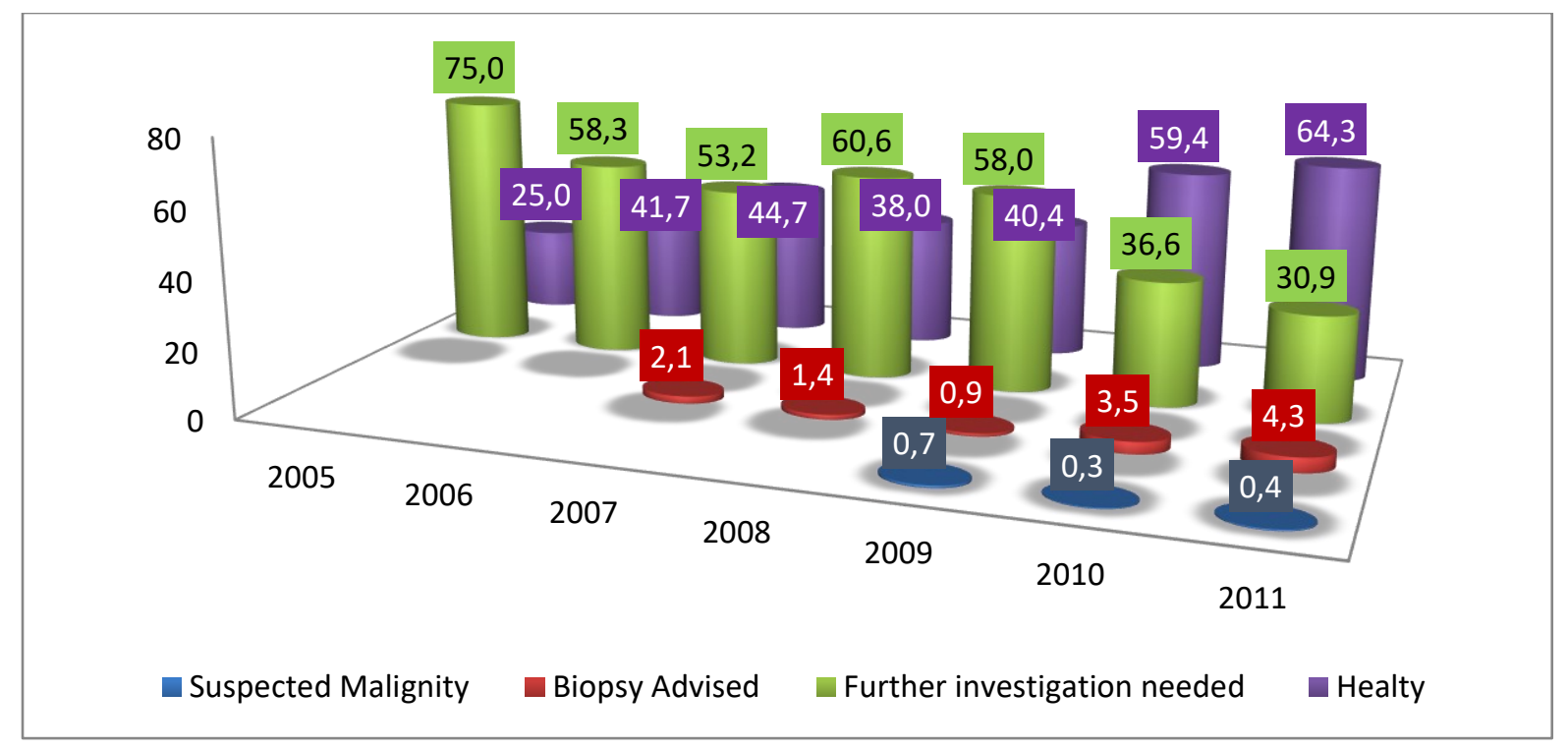

Figure 1. Mammography Screening Results According to Years

In 2007, 4.0\% additional follow-up was required, and malignancy was considered for $4.0 \%$. It required a follow-up of $2.0 \%$ until the end of June of 2011 , with biopsy suggestion for $0.8 \%$ malignancy diagnoses for $0.2 \%$ (Figure 2 ).

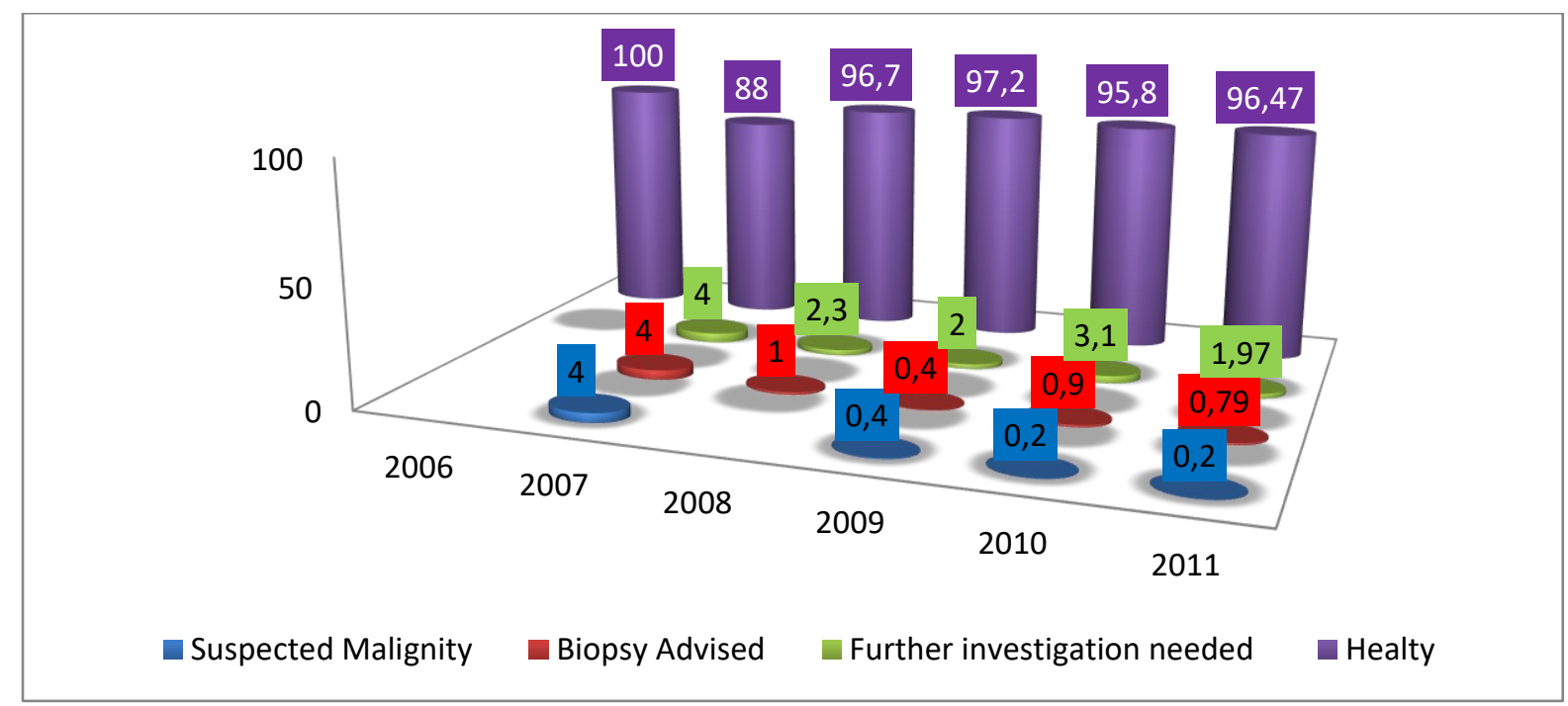

Figure 2. Cervical Screening Results According to Years

The biopsy was performed for $3.70 \%$ of the women screened by breast ultrasonography, $3.50 \%$ of those screened by mammography, and $2.90 \%$ of those screened by the cervical smear method. Thus, we can

\section{DISCUSSION}

In this study, there was an evaluation of reports of 3162 women, who attended screening program, speculate that the community-based screening with the teamwork of family medicine health workers and radiology-general surgery-pathology specialists were successful in reaching the target.

from 2005 until 30 June 2011. Education studies and opportunistic screening were started in 2005. 
The initial step was the educational programs for the awareness of the aim and the method of breastcervix cancer screening, not only for the participants but also for the family medicine center healthcare workers. This ensured the targeted groups accessed the centers. In 2010, community-based screening started, and in 2011, 1012 women underwent mammograms, and 1271 , cervical smears. The contribution of the family physicians to the screening program supported the transition to community-based screening and increased the participation of educated and health-conscious women in the screening program. To inform the community, the family physicians gave appointments to the women and cervical smears had been taken at the family health-care centers by the healthcare workers of CEDSTC after education about cancer screening had been performed. By 2007, 160,672 women were living in Rize . ${ }^{12}$ This program has evolved to the mammography- trucks for the rural parts due to reach more women.

The increased numbers also show the success of the community-based screening program, supported by the Referral of family physicians. In $2011,64.30 \%$ were reported as healthy, $36.6 \%$ as an additional follow-up, $4.30 \%$ as a recommendation for biopsy, and $0.40 \%$ as malignancy.

The breast-feeding ratio of the women was high, while the smoking habit ratio was low. Almost all avoided a combination of hormone replacement therapy (HRT) and oral contraceptive pills $(92.70 \%)$.

Celik and et al reported that $71.1 \%$ of the women in their study never had mammography and $20 \%$ had at once on the advice of health careers. ${ }^{13}$ Istanbul Bahcesehir study found that $41.6 \%$ had mammography from a sample of 659 women between 40-69 years old. ${ }^{14,15}$ These studies had a target population for a selected area. In our study, mammography was performed for $67.90 \%$, and breast ultrasonography for $65.20 \%$; this shows that the target group has increased their mammography screening rates, indicates the success of communitybased scanning. Besides the analysis was conducted with the same core team (physician, general surgeon, pathologist, nurse, midwife, and secretary) from 2005 until 2011. This also allowed getting the information about the transition period directly (sending invitations letters to the target population didn't work but the guidance of family physicians made a significant increase in participation). Most of the women were working in agriculture (tea, hazelnut, citrus fruits mostly). The settlement of the women was at slope areas and hard to travel to the center of the city. ${ }^{16}$ Family physicians had informed the women and the health board has supported by ensuring transport. "Person-centered approach", and "family-centered approach" of the family physicians make the difference for preventive care. ${ }^{17}$ By this way, not only the women who lived in the center of the city but also the women who lived in rural parts involved the program.

When women who participated in the cervical cancer screening program in the Netherlands were examined, it was determined that the participation by Turkish women who were not literate in the Dutch language, emphasizes the importance of family physicians' cooperation with women's understanding of how the screening program is implemented, and their participation. ${ }^{18}$ In the 2011 study of Korean National Cancer Screening Results, $22.10 \%$ of females had less than 11 years of education, while $53.3 \%$ studied between $12-14$ years. ${ }^{19}$ In our study, only $3.4 \%$ had higher education. It is important to define the level of education of the target women because it will affect the determination of the methods encouraging for participation, and the implementation of the screening program. In 2018, European Union (EU) reports an article, which presents statics on "early leavers from education and training in EU”, Turkey reported as having the highest levels of dropout from education $(35 \%)$.

These "early leavers from education and training" may be considered to face difficulties in finding suitable jobs with social insurance. ${ }^{20}$ So family physicians working in Turkey may also encounter women with low levels of education while "health literacy status" of the women also have an adjuvant effect on promoting health. ${ }^{3}$ Only $3.40 \%$ of the women who were participated in our study were in regular employment (gaining salary from social insurance cover). This "work status" may be employed as casual agriculture workers in addition to their domestic work, but these jobs were not covered by social insurance. ${ }^{21}$

Researchers that investigated attitudes of women towards the screening programs in Turkey, reported marriage rates as $60.6-95 \%$. ${ }^{22-25}$ Women Health Study reported that $65.70 \%$ of the women at 15-65 years old were married. ${ }^{6}$ Korea study reported the participants of the screening program as $80 \%$ married while Finnish study detected as 57.6\% married, $21.6 \%$ single, and $18.7 \%$ divorced. ${ }^{19,26}$ In our study, the marriage rate was $98.10 \%$ in comparison with international studies this was the highest rate. However, single women, divorced women, and LGBT individuals should also be involved in these programs.

Early menarche is one of the risk factors for breast cancer. ${ }^{27}$ In the study of women's health, Turkish women were found to have a mean age of menarche of 13 years 2014), and in our study, it was 
14 years. Having first birth at the age of 30 years or older is another risk factor for breast cancer. ${ }^{25}$ In the research of IARC, 22 countries were involved and the breast cancer diagnosed women were excluded from the study group. In South African, Iranian and Israeli Arab, the first birth age was found to be under the age of 23 in $70 \%$ of women. ${ }^{28}$ It is seen that the risk of breast cancer decreases for women living in Rize in terms of first birth age.

Breastfeeding reduces breast cancer risk. ${ }^{29}$ In the study of Lee et al., women with breastfeeding histories between 13-24 months were found to have lower breast cancer risk than those without breastfeeding stories (RR: 0,6 CI: 95\% 0,5-1,1) ${ }^{30}$. Romieu et al reported that in Mexican women, breastfeeding reduced the risk of breast cancer. ${ }^{31}$ Breast-feeding the rates are $99 \%$ in Norway, $98 \%$ in Denmark, 97\% in Sweden, 91\% in Spain, 86\% in Germany, and $85 \%$ in Italy ${ }^{25}$. In our study, the breastfeeding rate is $93.6 \%$, a factor likely to reduce breast cancer risk.

The use of hormone replacement therapy (HRT) is considered an ethical risk for breast cancer. ${ }^{32}$ HRT exposure could increase breast cancer risk 1.7 times. ${ }^{33}$ In our study, $92.7 \%$ did not use HRT, representing a reduced risk.

According to the Istanbul Breast Cancer Consensus Report, breast cancer in the family, as well as the presence of some types of cancer in blood relatives, are seen as risks. ${ }^{34}$ It has been determined that women have a greater risk of breast cancer if there is a family history of cancer. ${ }^{35}$ In our study, $25.50 \%$ of the women had first-degree relatives cancer history, $14.20 \%$ had breast cancer in their family, and $14.60 \%$ lung cancer. Participants were also given information and resources of health literacy, not only about breast-cervix cancer but also about healthy-life styles.

While "community-based screening" is free for the target women, there must be alternative approaches for those who are at risk and cannot access services e.g. women with mental illness solutions include: "(1) motivators for obtaining mammograms, (2) fears and concerns, (3) shame and embarrassment, (4) the clinical environment, (5) provider-patient communication, and (6) the need for increased patient education". ${ }^{36}$

Some of the studies reported that not only men but also middle-aged women without spouses had higher risks for poor health behaviors compared to those with spouses. ${ }^{37}$ In addition, although the level of knowledge about screening programs is high among healthcare workers are high, the participation of screening programs is low. ${ }^{38}$ In our study, most women were married. However, women with disabilities, "working class", single or divorced women, and LGBT individuals should be considered in these programs, too.

\section{Strengths and limitations}

Our analysis was conducted with the same core team (physician, general surgeon, pathologist, nurse, midwife, and secretary) from 2005 until 2011. This also allowed us to get the information about the transition period directly (the invitations letters to the target population did not work but the guidance of family physicians made a significant increase in participation).

In 2010, the radiologists due to decrease unnecessary breast operation (the same mammography was reported by two different radiologists) used the "double-blind method". We couldn't get any published data about these results from the centers.

Another limitation of this study is the lack of information about cancer diagnosed women's follow-ups; because some of the patients get their main surgery in one of the city but radiotherapy/chemotherapy in another city. Moreover, our study does not register the degree of the severity of cancer.

\section{Conclusion}

Although "community-based screening" represents a milestone, with the active participation of family physicians, in reaching the target population, new options should be considered for the women who are not able, for any reason, to participate in the breast and cervical cancer screening programs including healthcare workers.

\section{References}

1. Torre LA, Bray F, Siegel RL, Ferlay J, LortetTieulent J, Jemal A. Global cancer statistics, 2012. CA: a cancer journal for clinicians. 2015;65(2):87-108.

2. Siegel RL, Miller KD, Jemal A. Cancer statistics, 2019. CA: a cancer journal for clinicians. 2019.

3. Keskin OÖ, Çağlayan Ç. The Relationship Between Participation in Mammography Screening Program and Health Literacy. Turkish Journal of Family Medicine and Primary Care.13(4):448-456.

4. Gültekin M, Boztaş G. Türkiye kanser istatistikleri. Să̆lık Bakanlı̆̆l, Türkiye Halk Să̆lı̆̆ Kurumu. 2014;43. 
5. Houssami N, Irwig L, Ciatto S. Radiological surveillance of interval breast cancers in screening programmes. The Lancet. Oncology. Mar 2006;7(3):259-265.

6. Bakanlığı TCS. Türkiye Kadın Sağlığ 1 Araştırması. Ocak2014.

7. Harman Ö. Hacettepe Üniversitesi Tip Fakültesi Medikal Onkoloji Bölümü'ne başvuran meme kanserli hastalarda risk faktörlerinin dăğlımı [Uzmanlık Tezi]. Ankara : , Hacettepe Üniversitesi Tıp Fakültesi,; 2007.

8. Haydaroğlu A, Bölükbaşı Y, Özsaran Z. Ege Üniversitesi'nde kanser kayıt analizleri: 34134 olgunun değerlendirmesi. Türk Onkoloji Dergisi. 2007;22(1):22-28.

9. www.tuik.gov.tr/. İstatistiklerle Türkiye. www.tuik.gov.tr/. Accessed 19.11.2015, 2015.

10. Sabik LM, Tarazi WW, Hochhalter S, Dahman B, Bradley CJ. Medicaid Expansions and Cervical Cancer Screening for Low-Income Women. Health services research. 2017.

11. Mokdad AH, Marks JS, Stroup DF, Gerberding JL. Actual causes of death in the United States, 2000. Jama. Mar 10 2004;291(10):1238-1245.

12. Başaran S. Cumhuriyet Dönemi Rize Nüfusu. Firat Üniversitesi Sosyal Bilimler Dergisi. 2020;30(1):485-503.

13. Çelik GO, Malak AT, Öztürk Z, Yilmaz D. Menapoz Sonrası Dönemdeki Kadınların Kendi Kendine Meme Muayenesini Uygulama, Mamografi Çektirme ve Pap Smear Yaptırma Durumalrının İncelenmesi. AJCI. 2009;3(3):159-163.

14. Ozmen V, Nilufer Ozaydin A, Cabioglu N, et al. Survey on a mammographic screening program in Istanbul, Turkey. The breast journal. May-Jun 2011;17(3):260-267.

15. Özmen V. Breast cancer screening: current controversies. J Breast Health. 2011;7:1-4.

16. Dilek D. Türkiye'de Tarım Sektöründe, Kadın. Istanbul: Social Sciences, Marmara University; 2013.

17. Rakel RE, Rakel D. Textbook of family medicine. 8th ed. ed: Elsevier Health Sciences; 2011.

18. van Leeuwen AW, de Nooijer P, Hop WC. Screening for cervical carcinoma. Cancer. Oct 25 2005;105(5):270-276.

19. Son BH, Kwak BS, Kim JK, et al. Changing patterns in the clinical characteristics of Korean patients with breast cancer during the last 15 years. Archives of Surgery. 2006;141(2):155-160.

20. Commission E. Early leavers from education and training. 2018; http://ec.europa.eu/eurostat/statistics-
explained/index.php?title=Early leavers $\mathrm{f}$ rom education and training\#Analysis by sex, 2018.

21. Saraç H, Bölükbaşı ÖF, Sivri U. Rize İlinin Sosyo-ekonomik Gelişmişlik Düzeyinin İncelenmesi. Bildiriler Kitabi.372.

22. Aker S, Öz H, Tunçel EK. Samsun İlinde Yaşayan Yirmi Yaş Üstü Kadınların Meme Kanseri Risk Faktörleri Açısından Değerlendirilmesi. Meme Sagligi Dergisi/Journal of Breast Health. 2014;10(4).

23. Açıkgöz A, Çehreli R, Ellidokuz H. Kadınların Kanser Konusunda Bilgi ve Tutumları ile Erken Tanı Yöntemlerine Yönelik Davranışları. Dokuz Eylül Üniversitesi Tıp Fakültesi Dergisi. 2011.

24. Dündar P, Özmen D, Öztürk B, et al. The knowledge and attitudes of breast selfexamination and mammography in a group of women in a rural area in western Turkey. BMC cancer. 2006;6(1):1.

25. Aslan FE, Gürkan A. Kadinlarda meme kanseri risk düzeyi. Meme Să̆liği Dergisi. 2007;3:63-68.

26. Sarkeala T, Heinavaara S, Fredman J, et al. Design and respondent selection of a population-based study on associations between breast cancer screening, lifestyle and quality of life. BMC public health. 2015; $15: 1256$.

27. Colditz GA, Frazier AL. Models of breast cancer show that risk is set by events of early life: prevention efforts must shift focus. Cancer Epidemiology Biomarkers \& Prevention. 1995;4(5):567-571.

28. McCormack VA, Burton A, Dos-SantosSilva I, et al. International Consortium on Mammographic Density: Methodology and population diversity captured across 22 countries. Cancer epidemiology. Feb 2016;40:141-151.

29. Lipworth L, Bailey LR, Trichopoulos D. History of breast-feeding in relation to breast cancer risk: a review of the epidemiologic literature. Journal of the National Cancer Institute. 2000;92(4):302312.

30. Lee SY, Kim MT, Kim SW, Song MS, Yoon SJ. Effect of lifetime lactation on breast cancer risk: a Korean women's cohort study. International journal of cancer. 2003;105(3):390-393.

31. Romieu I, Hernández-Avila M, Lazcano E, Lopez L, Romero-Jaime R. Breast cancer and lactation history in Mexican women. American journal of epidemiology. 1996;143(6):543-552.

32. Chlebowski RT, Kuller LH, Prentice RL, et al. Breast cancer after use of estrogen plus 
progestin in postmenopausal women. The New England journal of medicine. Feb 5 2009;360(6):573-587.

33. Li CI, Malone KE, Porter PL, et al. Relationship between long durations and different regimens of hormone therapy and risk of breast cancer. Jama. Jun 25 2003;289(24):3254-3263.

34. Baskan S, Atahan K, Arıbal E, et al. Meme Kanserinde Tarama ve Tanı (ISTANBUL MEME KANSERI KONSENSUS KONFERANSI 2010). Meme Sagligi Dergisi/Journal of Breast Health. 2012;8(3).

35. Gokdemir-Yazar O, Yaprak S, Colak M, Yildirim E, Guldal D. Family history attributes and risk factors for breast cancer in Turkey. Asian Pacific journal of cancer prevention : APJCP. 2014;15(6):28412846.

36. Kahn LS, Fox CH, Krause-Kelly J, Berdine DE, Cadzow RB. Identifying barriers and facilitating factors to improve screening mammography rates in women diagnosed with mental illness and substance use disorders. Women \& health. 2005;42(3):111-126.

37. Kim A, Lee JA, Park HS. Health behaviors and illness according to marital status in middle-aged Koreans. Journal of public health (Oxford, England). Jun 1 2018;40(2):e99-e106.

38. Aker EB, Vural EZT, Aker S. Knowledge, Attitudes and Practices of Female Healthcare Providers Regarding Breast Cancer. Turkish Journal of Family Medicine and Primary Care.13(4):532541.

"Funding: This study was not funded."

"The authors declare that they have no conflict of interest."

"The authors would like to thank the public health directorate for their permission to evaluate data and Simon Edward Mumford for his great contribution in editing the language of the manuscript. " 